\title{
Education in the city of Ufa: digital environment as a condition for improving the quality of ethnocultural training of teachers
}

\author{
Alfiya Akchulpanova ${ }^{1 *}$, Irina Boronilova $^{1}$, Nelli Syrtlanova ${ }^{1}$, Guzel Shabayeva ${ }^{1}$, and Yelena \\ Pilipenko ${ }^{1}$ \\ ${ }^{1}$ Bashkir State Pedagogical University named after M. Akmulla, Institute of Pedagogy, Department of \\ Preschool Pedagogy and Psychology, Ufa, Republic of Bashkortostan, Russia
}

\begin{abstract}
This article discusses search of adequate tools for training of psychological and pedagogical staff of preschool education institutions, aiming at improvement of living quality in city, under conditions of electronic education for working in ethnocultural environment of preschool children. The choice of humanitarian approach assuming studying of personality as a subject of cultural self-development in education is theoretically substantiated. The contents of projects on training professional staff of the City of Ufa (Bashkiria) for preschool education institutions, as well as their advanced training in the frames of implementation of innovation technologies and practices have been determined. Some activities on training of teachers for working in ethnocultural kindergartens have been described. Experience of development of online courses aimed at formation of working activities related with ICT competences of participants in educational relations has been disclosed. The following projects have been presented: Network Electronic Kindergarten promoting efficient training of teachers for working in ethnocultural educational and digital environment of Bashkiria; Centers of competence development: Preschool Education Teacher, Electronic Education Teacher, as well as workshops of department of higher education entity on World Skills of Preschool Education competence disclosing opportunities to improve life quality in city.
\end{abstract}

Keywords: education of city, ethnocultural environment, digital environment.

\section{Introduction}

\subsection{Background}

The importance of investigation into the features of ethnocultural training of modern preschool teachers in accordance with modern requirements (including the challenges of global pandemic among others) has been analyzed at scientific theoretical and

* Corresponding author: akchulpan@mail.ru 
methodological levels as well as on the basis of practical demands: most kindergartens of Bashkiria are multinational, which determines the necessity of practical ethnocultural training of modern preschool teachers in changed conditions of educational practice: in digital environment.

\subsection{Literature review}

Analysis of the studies related with solution to separate aspects of ethnocultural education underlines both the interest in this topic by scientists and experts, and its importance at present (E.S. Babunova, S.D. Kirienko, O.L. Knyazeva, S.A. Kozlova, T.S. Komarova, L.V. Kolomiichenko, M.Yu. Novitskaya, N.P. Sakulina, E.V. Soloveva, R.M. Chumicheva, T.Ya.Shpikalova, etc.); the peculiarities of communication among children of various nationalities [1-5]; the role of national material and spiritual features of Bashkirs in education of preschool children [6]. At the same time, the analysis of educational practice demonstrates that in kindergartens of Bashkiria, the education is often based on monocultural principles. This complicates socialization of preschool children in multicultural educational environment and prevents complete implementation of tasks of ethnocultural education [712].

While analyzing the subject of this research, it is necessary to discuss the main definitions of this work: humanitarian approach, ethnocultural education, digital environment. In the field of preschool education, L.Yu. Dyachenko interprets ethnoculture as integration of aspects of personal characteristics, including: emotional and value-based attitude of a child to traditional culture; ability to characterize specific style of small folklore forms, peculiarities of musical and speech reproduction; studying folk traditions, customs, moral ideals and behavior norms; the skills of performing syncretism and the methods of creative communications formed in children of 5-7 years old [13].

A.B. Afanasyeva notes that ethnocultural educational is an integer process of practical studying of ethnocultural heritage (material, spiritual, social), formation and cultivation of a personality on the basis of cultural ethnic traditions combining monoethnic depth of comprehension of native culture and multiethnic width [14]. R.Kh. Gasanova considers education of preschool children as a comprehensive meaningful pedagogically organized process.

\section{Methods}

The technologies and methods of ethnocultural education in kindergartens were experimentally verified.

The projects of ethnocultural education using humanitarian approach could not be verified without updating the methods and technologies of activities, development of required modern site for formation of competences and accumulation of practical experience.

Training of teachers for working in ethnocultural education environment was supported by the Network Electronic Kindergarten project [15], which was developed and had been implemented for more than three years by the team of practical teachers (teachers of kindergartens in Bashkiria) and experts (teachers of the Department of Preschool Pedagogy and Psychology, Akmulla Bashkir State Pedagogical University). This project defined the following research and practical tasks: to develop the cognitive subjects (event-driven content) in accordance with most significant for children ethnocultural traditions, which would disclose geographic, historic, national and cultural features of Bashkiria (for instance, Sabantuy folk festival); to develop a packet of methodological specification of education organization in kindergarten under conditions of digital environment; to develop and to implement the program of advanced training of teachers; to form a bank of electron content, 
materials for teachers and parents in ethnocultural digital environment (online portal Network Electronic Kindergarten: http://kids.bspu.ru). Let us introduce brief statistical data of the project: development of 16 event-driven topics (cluster courses); participation of 12 partner kindergartens, 44 authors-teachers (innovators); 350 exercises and materials for parents were developed and verified; 16 pilot kindergartens were opened; 10 certified methodological experts were trained, including scientific degree in the project profile; 15,166 site views were recorded; 32 expert commissions were held to analyze education products of the project in digital and real environment; participation of 20 Bashkiria districts in verification and implementation of content plans of the project site was organized.

\section{Results and discussion}

The content of the online course is oriented at formation of actions related with mastering ICT competences, required and sufficient for planning, designing, implementation and estimation of education of young and preschool children. The main principle of the online program: soft via hard, that is, skills to operate with studied content and to apply them in various contexts of professional activity. The program content included training of preschool teachers to operate with interactive desk, floor, globe, board, panel, robotics and Legodesigning, cubes, as well as development of interactive games and supporting materials for teachers. The topics of online course presented certain infosystem, where a participant in education relations independently selected own topic, contacting with all the subjects of the educational relations. The following forms were used: forum, online conference, strategic sessions, briefings, etc. Such variety of the program topics, forms of independent assignments allowed for a kindergarten to select reporting form and methodological solutions (online tests, verification of methodological recommendations on the use of desk, board, globe, etc., development of rules, projects, interactive games, didactic material, etc.).

Peculiar feature of this program is that it promoted creation of conditions for personified education of preschool teachers oriented at design of opportunities, where subjective position of a teacher was the most important; determined personal rate of achievement of education target; allowed for selection of topics of online disciplines (working with interactive desk, interactive floor, board, globe, panel, sandbox, etc.); created the site for formation of the key competences of a modern teacher, such as creativity, critical thinking, communication, cooperation, as well as for mastering future professions in kindergarten: game technicians, game masters, which already appeared in 2020 (Atlas of New Professions); created opportunity environment for preschool teachers.

Completion of the online course was verified by the appropriate certificate (according to teacher choice: Modern electronic education teacher: algorithm of the use of interactive board, floor, globe; Modern electronic education teacher: the use of blackboard, panel, sandbox; Modern electronic education teacher: algorithm of the use of robotics and Legodesign; Modern electronic education teacher: the use of interactive cubes; Electronic education teacher: developer of interactive games and supporting materials). Activities were implemented in the centers of competence formation: Modern preschool education teacher, Modern electronic education teacher; expert consulting centers; workshops; innovation sites and basic preschool educational establishments of department of higher education entity on World Skills of Preschool Education competence.

\section{Conclusion}

Therefore, studying of the online program assisted preschool teachers (foreign language, bilingual group, multilingual group, choreography, physical culture, etc.) to solve 
professional problems, to initiate sphere of activity applying modern interactive equipment and technologies. Knowledge, activity cluster of experience acquired by preschool teachers during mastering the course system created motivated, theoretical and practical, scientific and methodological site for formation of skills and competences using the best world practices for participation in the contest of professional skills, WorldSkills Russia, in the field of Preschool Education. This trend is characterized by extensive field for studies.

\section{References}

1. N.Sh. Syrtlanova, G.F. Shabayeva, I.G. Boronilova, Ye.A. Pilipenko, EpSBS Journal, 93-HPEPA 2019, 886-897 (2019). https://doi.org/10.15405/epsbs.2020.11.92

2. G.F. Shabayeva, N.Sh. Syrtlanova, Problemy sovremennogo pedagogicheskogo obrazovaniya, 65(4), 268-272 (2019)

3. V.I. Baymurzina, Cooperant approach to the study of general ethnopedagogy (LAP Lambert Academic Publishing, Moscow, 2015)

4. G. Yerkibayeva, Obshchiye osnovy etnopedagogiki [General foundations of ethnopedagogy] (Palmarium Academic Publishing, Moscow, 2015)

5. E.F. Vertyakova, Teoretiko-metodologicheskiye aspekty regulirovaniya etnokul'turnykh otnosheniy $\mathrm{v}$ obrazovatel'nom prostranstve [Theoretical and methodological aspects of regulation of ethnocultural relations in the educational space] (Publishing house REKPOL, Chelyabinsk, 2006)

6. R.Kh. Gasanova, Sotsiokul'turnoye razvitiye detey doshkol'nogo vozrasta [Sociocultural development of preschool children] (Publishing house of Institute for the Development of Education of the Republic of Bashkortostan, Ufa, 2011)

7. L.V. Trubaychuk, Doshkol'noye detstvo kak razvivayushcheysya sotsiokul'turnyy fenomen [Preschool childhood as a developing socio-cultural phenomenon] (IRPO, Chelyabinsk, 2009)

8. I.G. Boronilova, A.M. Chirkova, Interaction between preschool educational institution and family in the formation of socio-cultural values of preschoolers, in Humanistic heritage of educators in culture and education. Materials of the XII International Scientific and Practical Conference, Bashkir State Pedagogical University named after M. Akmulla, 14 December 2017, Ufa, Russia, 224-226 (2018)

9. N.G. Panteleyeva, Voprosy doshkolnoy pedagogiki, 2(19), 1-4 (2019). Accessed on: December 27, 2020. [Online]. Available: https://moluch.ru/th/1/archive/115/3866

10. M.V. Korepanova, Izvestia of the Volgograd State Pedagogical University, 8(62), 5357 (2011)

11. B.S. Gershunsky, Filosofiya obrazovaniya [Philosophy of Education] (Moscow Psychological and Social Institute, Flinta, Moscow, 1998)

12. A.G. Gogoberidze, I.V. Golovina, Psychological Science and Education, 20(5), 99-107 (2015). https://doi.org/10.17759/pse.2015200509

13. L.Yu. Dyachenko, Formirovaniye osnov etnokul'tury u starshikh doshkol'nikov v muzykal'no-fol'klornoy deyatel'nosti [Formation of the foundations of ethnoculture among older preschoolers in musical and folklore activities], Thesis (Moscow Pedagogical University, Moscow, 2014)

14. A.B. Afanasyeva, Man and education, 4(17), 34-38 (2008) 
15. Internet portal "Network electronic kindergarten". Online education of the Republic of Bashkortostan. (n.d.). Accessed on: December 27, 2020. [Online]. Available:

http://kids.bspu.ru 